\title{
Product Quality Control Analysis with Statistical Process Control (SPC) Method in Weaving Section (Case Study PT.I)
}

\author{
$1^{\text {st }}$ Yusita Attaqwa, $2^{\text {nd }}$ Aqidatun Hamidiyah, $3^{\text {rd }}$ Firman Ardiansyah Ekoanindyo, \\ ${ }^{1.2}$ Program Studi Teknik Industri, Fakultas Teknik dan Rekayasa Universitas Selamat Sri \\ ${ }^{3}$ Program Studi Teknik Industri, Fakultas Teknik Universitas Stikubank Semarang \\ 1aqidatunhamidiyah@gmail.com, ${ }^{2}$ ermayana1802@gmail.com, ${ }^{3}$ firman@edu.unisbank.ac.id
}

\begin{abstract}
PT.I is a company that produces synthetic rattan furniture on an export scale. The various products at PT.I are an attraction for consumers, such as classic and modern weaving models. However, the number of defects produced is higher than the tolerance limit company. Based on data from the weaving section, it shows that there are 5 types of defects that are not in accordance with the standards and quality that have been determined by the company. The purpose of this study is to identify the types of defects that often occur in PT. I and identify the main factors causing product defects using the SPC method. The seven tools consist of a check sheet, histogram, stratification, scatter diagram, p control chart, Pareto diagram, and fishbone diagram. The results showed that the number of defects in October and November exceeded the limit set by the company. The highest level of disability occ urred in October. The higher the number of production, the higher the number of product defects. Based on the results of the p control chart, it can be seen that the product is outside the control limits that it should have. The process is in a state of uncontrollabi lity or is still experiencing deviations. To suppress or reduce the number of product defects that occur in production, 3 types of dominant defects can be applied, namely the woven model (254 units), loose woven (122 units), and nail-looking woven (119 units). Factors causing defects in production are derived from human factors/workers, methods, materials/raw materials and work environment.
\end{abstract}

Keywords: PT. I, Weaving, Product defects, SPC

\section{INTRODUCTION}

PT.I is a company that produces synthetic rattan furniture on an export scale. Various kinds of products in PT. I is an attraction for consumers, such as classic and modern weaving models. Weaving is a weaving process by overlapping (crossing) woven material in the form of synthetic rattan. The weaving process is very important in terms of product quality, however, in the weaving process, there are still non-conformances with the company's standards, such as the color of the woven material that is not the same, loose woven, dirty woven, visible woven nails or soldering, and twists/woven models. This can be seen in the weaving process in October-November 2020.

In accordance with the guidelines for the quality objectives of PT. I that the product is said to be of high quality if the conformity between the production results produced with the standard target plan set by the company at the beginning of each production and the riject target or cumulative riject product is not more than $5 \%$ of the total production. If the number of riject products is more than $5 \%$, of course it will be a loss for the company because it causes waste in production. Thus, it means that the product quality control program implemented by the company is not optimal, so it is necessary to analyze the quality control efforts implemented by PT. I and look for the cause of the occurrence of riject products as well as looking for repair solutions using statistical tools can help and simplify the interpretation of quality problems into a visual table or graphic display so that the percentage of riject products can be reduced to a minimum.

Referring to the description above, it can be seen that the problem of quality control is a very important matter and requires a more in-depth study. Therefore, researchers consider research in the field of quality control is very important in supporting companies to have competitiveness with other companies' products.

\section{RESEARCH METHODS}

The research location is at PT.I which is located at Jalan Soekarno-Hatta Km. 19 Dukuh Kuwayuhan RT. 001/RW. 002 Nolokerto Village, Kaliwungu District. Data collection techniques used are check lists, interviews, observation and documentation. In processing the data obtained, statistical tools are used in statistical process control (SPC). the steps taken are by collecting data using check sheets, making histograms, making stratification, making scatter diagrams (scatter diagrams), making $\mathrm{p}$ control charts, determining improvement priorities using Pareto diagrams, looking for dominant causal factors with fishbone diagrams and making suggestions. quality improvement. 
International Journal of Computer and Information System (IJCIS)

Peer Reviewed - International Journal

Vol : Vol. 02, Issue 03, Agustus 2021

e-ISSN : 2745-9659

https://ijcis.net/index.php/ijcis/index

\section{Flow diagram}

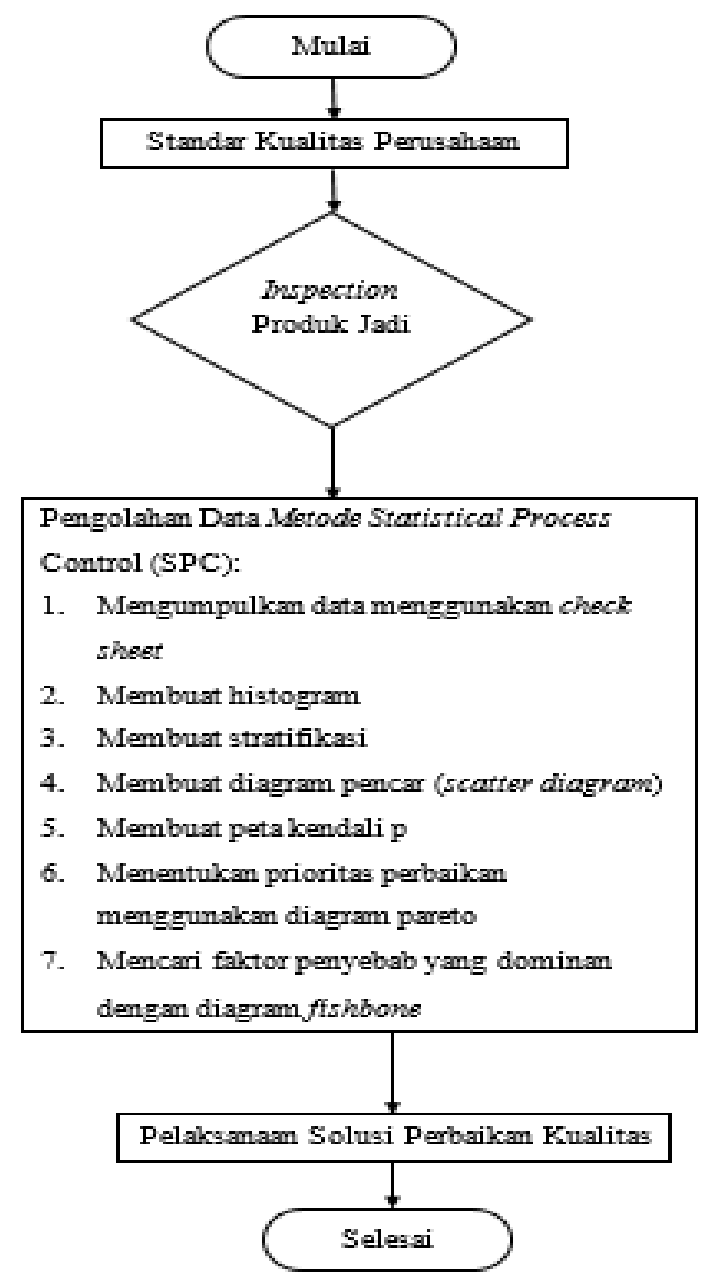

\section{RESULTS AND DISCUSSION}

The weaving process in the production process at PT.I is still found to be incompatible with products with company standards so that quality control is needed. Statistical quality control using statistical process control (SPC) has 7 (seven) main statistical tools that can be used as tools to control quality as also mentioned by Rendi Kaban (2014:523), including: check sheets, histograms, control charts, Pareto diagrams, cause-and-effect diagrams, scatter diagrams, and process diagrams.

\section{October Data Processing}

\section{Collecting data using check sheets}

In carrying out statistical quality control, the first step to be taken is a check sheet. The results of data collection through check sheets that have been carried out can be seen in Table 1 as follows:
Table 1. Weaving Part Production Report for October 2020

\begin{tabular}{|c|c|c|c|c|c|c|c|c|}
\hline \multirow{2}{*}{ Tangogal } & \multirow{2}{*}{ Jumlah Produks } & \multicolumn{5}{|c|}{ Jenis Misdruk } & \multirow{2}{*}{\begin{tabular}{|l|l} 
Jumlah \\
Misdruk
\end{tabular}} & \multirow{2}{*}{\begin{tabular}{|l} 
Persentase \\
Misdruk $(\%$
\end{tabular}} \\
\hline & & Wama Bahan & Anyaman Kendor & or Anyaman Kotor & Anyaman Terthat Paku & Model Anyaman & & \\
\hline 1 & 122 & 0 & 3 & 1 & 3 & 3 & 10 & 8,2 \\
\hline 2 & 156 & 0 & 4 & 0 & 7 & 5 & 16 & 10,3 \\
\hline 3 & 170 & 0 & 5 & 0 & 3 & 17 & 25 & 14,7 \\
\hline 4 & 109 & 0 & 6 & 0 & 0 & 0 & 6 & 5,5 \\
\hline 5 & 145 & 1 & 3 & 2 & 3 & 0 & 9 & 6,2 \\
\hline 6 & 96 & 0 & 0 & 0 & 0 & 5 & 5 & 5,2 \\
\hline 7 & 105 & 0 & 10 & 0 & 3 & 4 & 17 & 16,2 \\
\hline 8 & 158 & 1 & 7 & 3 & 0 & 2 & 13 & 8,2 \\
\hline 9 & 115 & 2 & 15 & 0 & 5 & 3 & 20 & 17,4 \\
\hline 10 & 233 & 10 & 5 & 1 & 4 & 10 & 30 & 12,9 \\
\hline 11 & 112 & 2 & 7 & 3 & 3 & 10 & 25 & 22,3 \\
\hline 12 & 185 & 10 & 1 & 1 & 5 & 15 & 31 & 16,8 \\
\hline 13 & 98 & 1 & 2 & 2 & 5 & 9 & 19 & 19,4 \\
\hline 14 & 84 & 15 & 4 & 1 & 1 & 1 & 22 & 26,2 \\
\hline 15 & 183 & 3 & 1 & 3 & 3 & 5 & 15 & 8,2 \\
\hline 16 & 125 & 4 & 2 & 1 & 2 & 1 & 10 & 8,0 \\
\hline 17 & 100 & 0 & 5 & 2 & 7 & 3 & 15 & 15,0 \\
\hline 18 & 137 & 1 & 1 & 2 & 3 & 10 & 17 & 12,4 \\
\hline \begin{tabular}{|l|}
19 \\
\end{tabular} & 119 & 2 & 1 & 3 & 5 & 2 & 13 & 10,9 \\
\hline Total & 2552 & 52 & 82 & 25 & 62 & 105 & 318 & 12,8 \\
\hline
\end{tabular}

Source: Processed primary data, 2020

\section{Create a histogram diagram}

To make it easier to see more clearly the misdruk that occurred in accordance with the table above, the next step is to make a histogram. The misdruk product data is presented in the form of a bar graph which is divided based on the type of each misdruk.

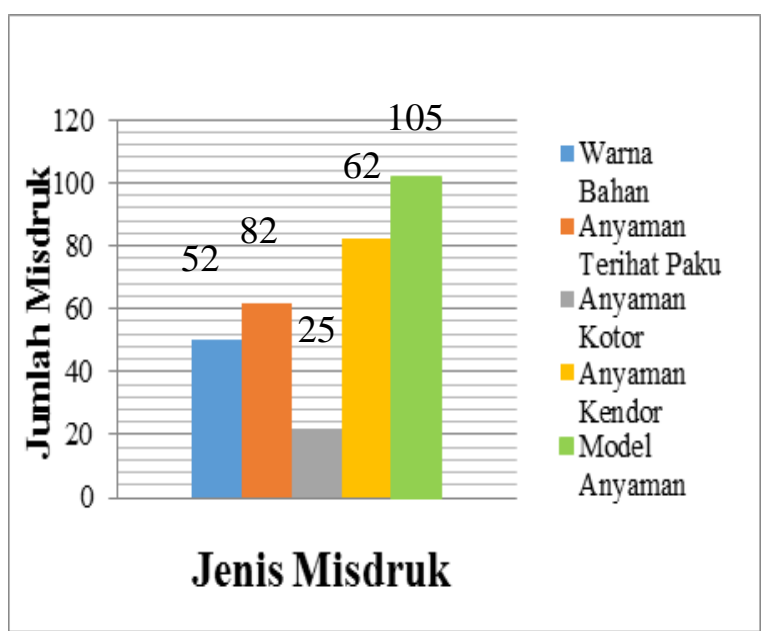

Figure 1. Histogram Diagram of Weaving Section Damage Types for October 2020

3. Make stratification to show problems by group Of the total number of 2,552 units inspected, 2,234 units were of good quality and 310 units were declared defective. Table 2 is the result of the data stratification as follows: 
International Journal of Computer and Information System (IJCIS)

Peer Reviewed - International Journal

Vol : Vol. 02, Issue 03, Agustus 2021

e-ISSN : 2745-9659

https://ijcis.net/index.php/ijcis/index

Table 2 Weaving Section Product

Stratification in October

\begin{tabular}{|l|c|c|c|c|}
\hline \multicolumn{2}{|c|}{ Jenis Cacat } & \multirow{2}{*}{ Frekuensi } & \multirow{2}{*}{ Persentase } & \multirow{2}{*}{ Akumulasi } \\
\hline Anyaman Kotoran & Simbol & & & \\
\hline Warna Bahan & 1 & 22 & $7 \%$ & $7 \%$ \\
\hline Anyaman Terlihat Paku & 2 & 50 & $16 \%$ & $23 \%$ \\
\hline Anyaman Kendor & 3 & 62 & $19 \%$ & $42 \%$ \\
\hline Model Anyaman & 5 & 82 & $26 \%$ & $68 \%$ \\
\hline \multicolumn{2}{|c|}{ Jumlah } & 3102 & $32 \%$ & $100 \%$ \\
\hline
\end{tabular}

4. Create a scatter diagram (Scatter Diagram)

Based on Table 2 the scatter diagram is as follows:

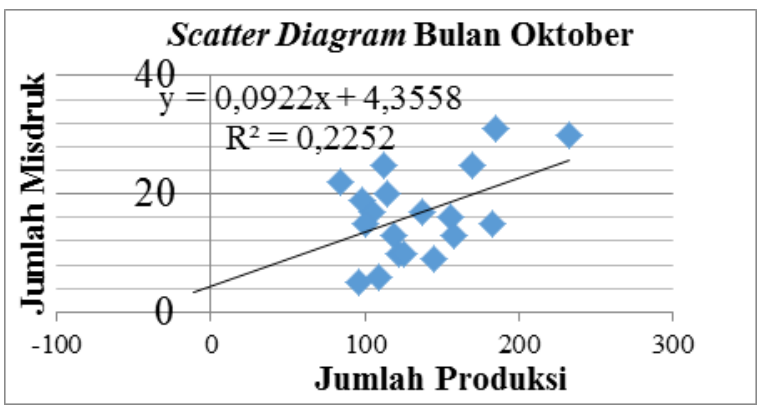

Figure 2 Scatter Diagram for October Weaving Section

From the resulting graphic form, the graph from the scatter diagram above is stated to have a positive relationship (positive correlation) which means that the higher the amount of production, the higher the level of damage. Judging from the equation of the line in Figure 2, that the pattern of the amount of production has a positive influence on the number of misdruk or the amount of damage of 0.0922 parts and other effects of 4.3558 .

\section{Create a P Control map}

P Control Map which can be seen in Figure 3.

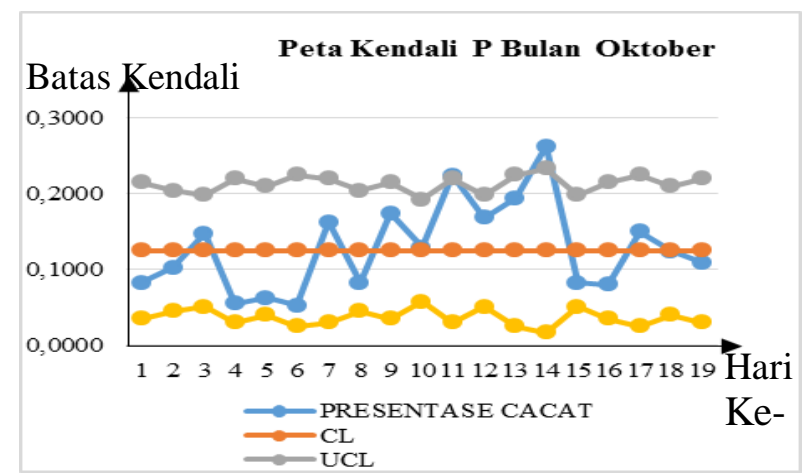

Figure 3. P . Control Map

Based on the P control chart above, it can be seen that the data obtained are not entirely within the predetermined control limits, even many are out of the control limits, only 1 (one) point is almost close to the control limit, namely on the 19th day. The highest value is on the 14th day and the lowest is on the 4th and k-6th day. This shows that the highest deviation occurs.

6. Determine improvement priorities using Pareto diagrams

The next calculation is carried out by analysis, the following is Table 4 of the number of defects during October 2020:

Table 4 Number of Frequency of Types of Disability (by order of number) in October 2020

\begin{tabular}{|c|c|c|c|c|}
\hline \multicolumn{2}{|c|}{ Jenis Cacat } & \multirow{2}{*}{ Frekuensi } & \multirow{2}{*}{ Persentase } & \multirow{2}{*}{ Akumulasi } \\
\hline Keterangan & Simbol & & & \\
\hline Model Anyaman & 1 & 152 & $49 \%$ & $49 \%$ \\
\hline Anyaman Kendor & 2 & 57 & $18 \%$ & $67 \%$ \\
\hline Warna Bahan & 3 & 41 & $13 \%$ & $80 \%$ \\
\hline Anyaman Terlihat Paku & 4 & 40 & $13 \%$ & $93 \%$ \\
\hline Anyaman Kotor & 5 & 20 & $7 \%$ & $100 \%$ \\
\hline \multicolumn{2}{|l|}{ Jumlah } & 310 & $100 \%$ & \\
\hline
\end{tabular}

Based on the data above, a Pareto diagram can be drawn up as shown in Figure 4 below:

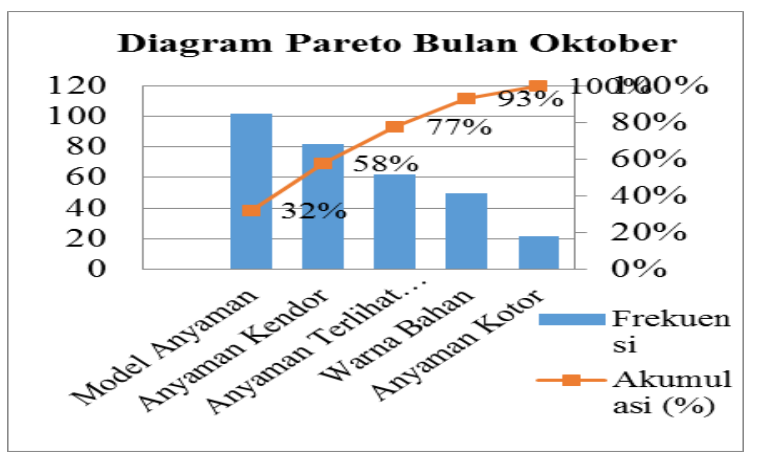

Figure 4. Pareto Diagram of Damage Types in October (Source: Table 3)

Based on observations, it can be seen that the highest percentage of damage in October was the woven model with a percentage of $32 \%$, and the lowest damage was gross woven with a percentage of $7 \%$.

\section{November Data Processing}

\section{Collecting data using check sheets}

The following production data for November 2020 can be seen in Table 5: 
International Journal of Computer and Information System (IJCIS)

Peer Reviewed - International Journal

Vol : Vol. 02, Issue 03, Agustus 2021

e-ISSN : 2745-9659

https://ijcis.net/index.php/ijcis/index

Table 5. Weaving Part Production Report for November 2020

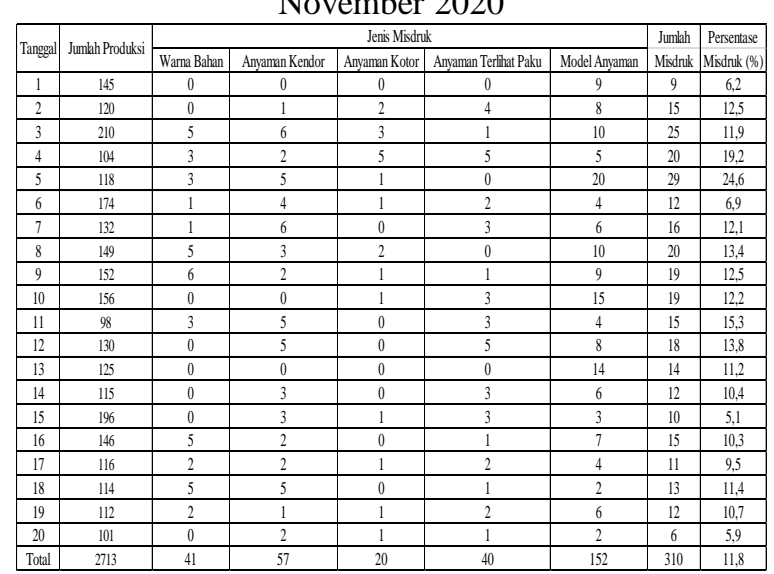

2. Create a histogram

After making the stratification made, the next step is to create a histogram. This histogram is useful for seeing the type of damage that occurs the most. The following histogram is made based on Table 6 is as follows:

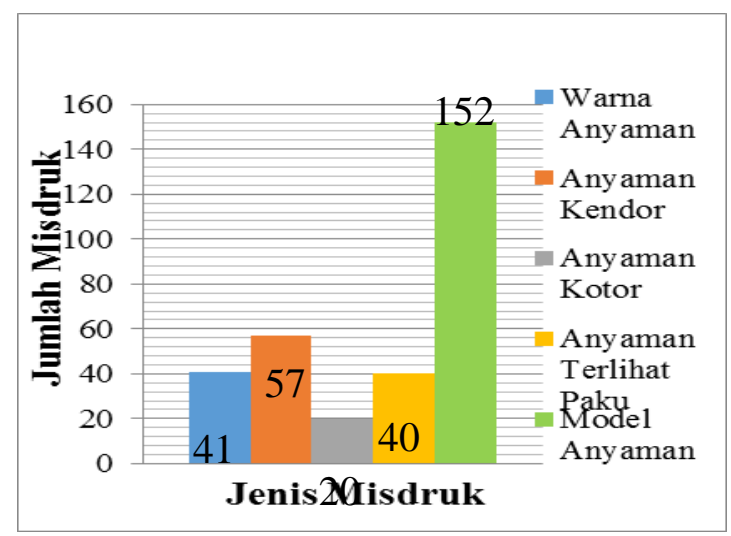

Figure 5. Histogram Diagram of Production Damage Types for November 2020

Based on Figure 5. It can be seen that the highest damage in November was the woven model with a total of 152 and the lowest damage was the gross woven with a total of 23 .

\section{Stratify to show problems by group}

Of the total number of units inspected as many as 2,713 units, there were 2,403 units of good quality and 310 units that were declared defective. Table 7 is the result of the data stratification as follows:
Table 6 November 2020 Stratification

\begin{tabular}{|l|c|c|c|c|}
\hline \multicolumn{2}{|c|}{ Jenis Cacat } & \multirow{2}{*}{ Frekuensi } & \multirow{2}{*}{ Persentase } & Akumulasi \\
\cline { 1 - 2 } Model Anyaman & Simbol & & & \\
\hline Anyaman Kendor & 1 & 152 & $49 \%$ & $49 \%$ \\
\hline Warna Bahan & 2 & 57 & $18 \%$ & $67 \%$ \\
\hline Anyaman Terlihat Paku & 3 & 41 & $13 \%$ & $80 \%$ \\
\hline Anyaman Kotor & 4 & 40 & $13 \%$ & $93 \%$ \\
\hline \multicolumn{2}{|c|}{ Jumlah } & 20 & $7 \%$ & $100 \%$ \\
\cline { 1 - 2 } & 510 & $100 \%$ & \\
\end{tabular}

4. Create a scatter diagram (Scatter Diagram)

Based on Table 6 above, the November scatter diagram is as follows:

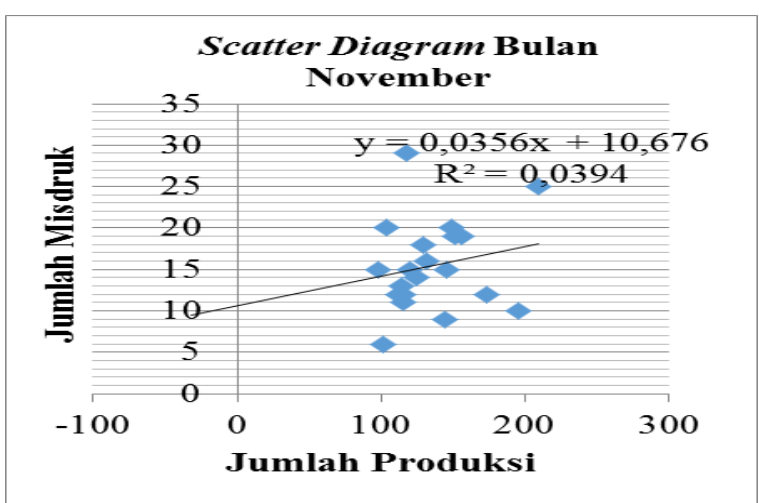

Figure 6 Scatter Diagram for November 2020

From the resulting graphic form, the graph from the scatter diagram above is stated to have a positive relationship (positive correlation) which means that the higher the amount of production, the higher the level of damage. Judging from the equation of the line in Figure 6, that the pattern of the amount of production has a positive influence on the amount of misdruk or the amount of damage of 0.0922 parts and other effects of 4.3558 .

\section{Create a $\mathbf{P}$. control chart}

The p control chart can be seen in Figure 7 below:

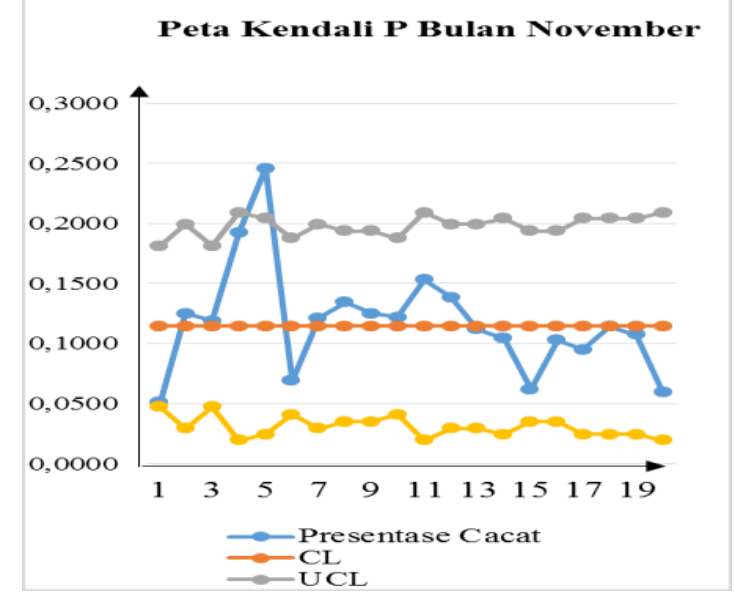

Figure 7. P Control Map for November 2020 
In the picture above, it can be seen that the 20 samples taken fall into the control limit. The highest value is on the 5th day and the lowest is on the 1st day. This shows that the highest deviation occurs.

\section{Determine improvement priorities using Pareto diagrams}

In Table 6. It can be seen that these types of defects occur during the production process, so they can be rejected or separated from good products so that they do not reach the hands of consumers.

Table 8. Number of Frequency of Types of Disability (in order of number) in November 2020

\begin{tabular}{|c|c|c|c|c|}
\hline \multicolumn{2}{|c|}{ Jenis Cacat } & \multirow{2}{*}{ Frekuensi } & \multirow{2}{*}{ Persentase } & \multirow{2}{*}{ Alumulasi } \\
\hline Keterangan & Simbol & & & \\
\hline Model Anyaman & 1 & 152 & $49 \%$ & $49 \%$ \\
\hline Anyaman Kendor & 2 & 5 & $18 \%$ & $67 \%$ \\
\hline Warna Bahan & 3 & 41 & $13 \%$ & $80 \%$ \\
\hline Anyaman Terlinat Paku & 4 & 40 & $13 \%$ & $93 \%$ \\
\hline Anyaman Kotor & 5 & 20 & $7 \%$ & $100 \%$ \\
\hline \multicolumn{2}{|l|}{ Jumlah } & 310 & $100 \%$ & \\
\hline
\end{tabular}

Source: Table 6

Based on the data above, a Pareto diagram can be drawn up as shown in Figure 8 below:

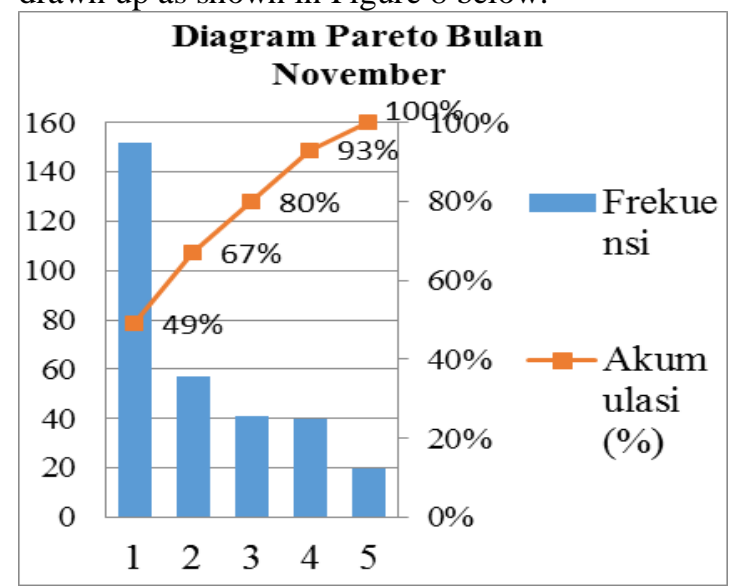

Figure 8 Pareto Chart for November 2020

Based on observations, it can be seen that the highest percentage of damage in November was the woven model with a percentage of $49 \%$, the second was loose woven with a percentage of $18 \%$, the third was the visible nail matting with a percentage of $13 \%$, the fourth was the color of the material with a percentage of $13 \%$, the most damage the lowest is the gross webbing with a percentage of $7 \%$. From the Pareto chart calculations for October and November 2020, the number of defects is still outside the tolerance limit given by the company. For this reason, the types of defects were analyzed using a fishbone diagram. The following is the number of defects for the months of October and November:

Table 9 Total Misdruk in October and November 2020

\begin{tabular}{|l|c|c|c|}
\hline \multirow{2}{*}{ Jenis Misdruk } & \multicolumn{2}{|c|}{ Bulan } & \multirow{2}{*}{ Total } \\
\cline { 2 - 3 } & Oktober & November & \\
\hline Model Anyaman & 102 & 152 & 254 \\
\hline Anyaman Kendor & 82 & 40 & 122 \\
\hline Anyaman Terlihat Paku & 62 & 57 & 119 \\
\hline Warna Bahan & 50 & 41 & 91 \\
\hline Anyaman Kotor & 22 & 20 & 42 \\
\hline \multicolumn{1}{|c|}{ Total } & 318 & 310 & \multicolumn{1}{|c|}{} \\
\hline
\end{tabular}

So, repairs can be made by focusing on the 3 biggest types of defects or misdruk, namely the model of woven, loose woven, woven with visible nails.

\section{Finding the dominant causative factor with a fishbone diagram}

After knowing the types of defects that occur, PT.I needs to take corrective steps to prevent similar damage from occurring. As a tool to find the cause of the damage, a fishbone diagram is used. The use of fishbone diagrams to identify the type of each damage that occurs is as follows:

a. Woven Model

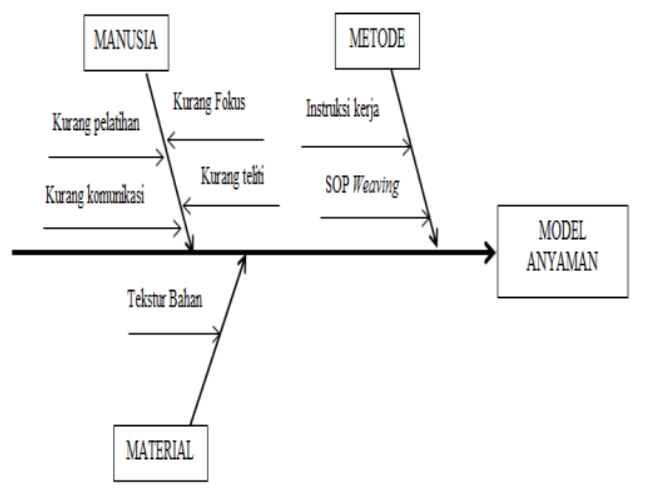

Figure 9. Woven Model

Source: Results of Field Observations and Interviews

b. Loose Webbing

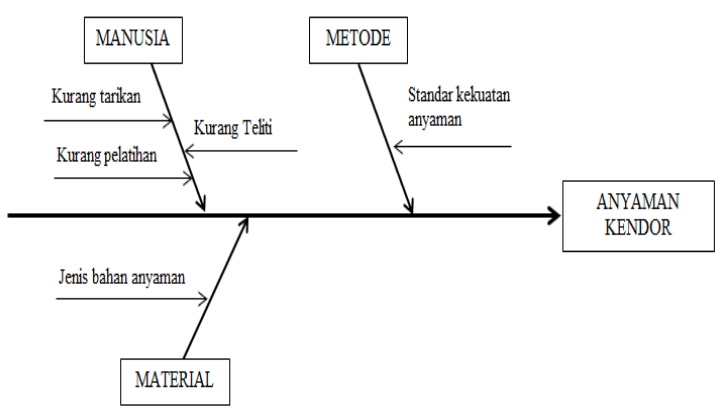

Figure 10. Loose Webbing

Source: Results of Field Observations and Interviews 
c. Webbing Looks Nails

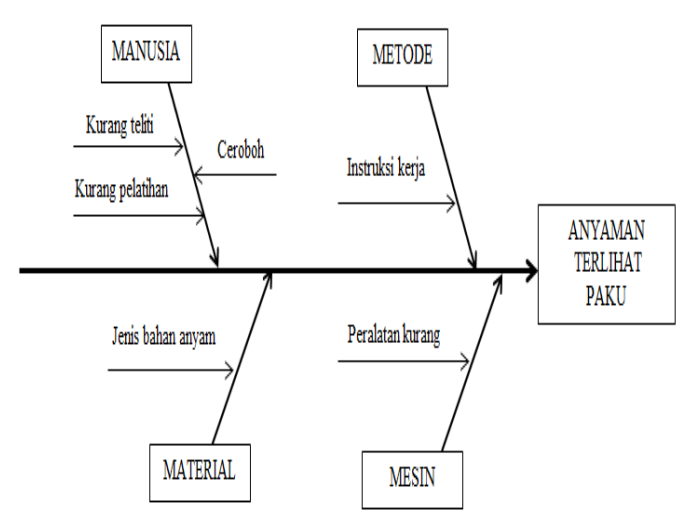

Figure 12. Webbing Looks Nails

Source: Results of Field Observations and Interviews

\section{Proposed Corrective Action}

1. Proposed action for the woven model

Provide specifications to the weaving QC team inside the factory or outside the new factory or warehouse, because different weaver places make the QC team lack of communication and monitoring. For this reason, unifying perceptions among the $\mathrm{QC}$ team is the goal to minimize the damage to the weaving model afterwards.

2. Proposed action for slack webbing

Determine the standard of webbing strength during the process. With the standard webbing strength, it can be used as a reference when pulling webbing.

3. Proposed action for woven visible nails

Add tools such as hammers, shooting tools, screwdrivers, soldering irons so that when the tool is damaged or lacking, there is still a stock of tools. For novice employees, training is given on how to weave so that the webbing does not look like nails. In addition, employees need to know about the types of woven materials to be processed.

\section{CONCLUSION}

1. Production data obtained from PT. It is known that the average defect in October in each production is $12.8 \%$. The average disability in November was $11.8 \%$. The company's tolerance for defects in each production is $5 \%$, so the number of defects in October and November exceeds the limit set by the company.

2. The highest defect rate in October was 102 units of woven model, 82 units of loose webbing, 62 units of nail-looking woven, 50 units of colored woven and 22 units of gross woven.

3. The higher the number of production, the higher the number of product defects.
4. Based on the results of the p control chart, it can be seen that the product is outside the control limits that it should have. This is an indication that the process is in an uncontrolled state or is still experiencing deviations.

5. Based on the Pareto diagram, priority improvements that need to be made by PT. In order to suppress or reduce the number of product defects that occur in production, 3 types of dominant defects can be applied, namely the woven model (254 units), loose woven (122 units), and nail-looking woven (119 units).

6. From the analysis of the fishbone diagram, it can be seen that the factors that cause defects in production are derived from human factors/workers, methods, materials/raw materials and the work environment.

\section{ACKNOWLEDGMENTS}

All directors and employees of PT. I

\section{REFERENCES}

[1.] Assauri, Sofyan. 1998. Manajemen Operasi Dan Produksi. Jakarta:LP FE UI

[2.] Darsono.2013. Analisis Pengendalian Kualitas Produksi dalam upaya Mengendalikan Tingkat Kerusakan Produk.Jurnal Ekonomi. 1-17

[3.] Elmas, Muhammad Syarif Hidayatullah. 2017. Pengendalian Kualitas Dengan Menggunakan Metode Statistical Quality Control (SQC) Untuk meminimumkan Produk Gagal Pada Toko Roti Barokah Bakery. Jurnal Penelitian Ilmu Ekonomi. 6. 15-22.

[4.] Fakhri, Al Faiz. 2010. Analisis Pengendalian Kualitas Produksi di PT. Masscom Grahpy dalam Upaya Mengendalikan Tingkat Kerusakan Produk Menggunakan Alat Bantu Statistik. Skripsi. Fakultas Ekonomi. Universitas Diponegoro. Semarang

[5.] Hartini, S. 2012. Peran Inovasi: Pengembangan Kualitas Produk dan Kinerja Bisnis. Jurnal Manajemen dan Kewirausahaan. 18-88

[6.] Ilham, Nur Muhammad. 2012. Analisis Pengendalian Kualitas Produk dengan Menggunakan Statistical Processing Control (SPC) pada PT. Bosowa Media Grafika (Tribun Timur).Skripsi.Fakultas Ekonomi dan Bisnis. Universitas Hasanuddin. Makasar.

[7.] Kaban, Rendy. 2014. Pengendalian Kualitas Kemasan Plastik Pouch Menggunakan Statistical Process Control (SPC) Di PT Incasi Raya Padang.Jurnal Optimasi Sistem Industri. 518-547.

[8.] Kartika, Hayu. 2013. Analisis Pengendalian Kualitas Produk CPE Film dengan Metode Statistical Process Control pada PT. MSI. Jurnal Ilmiah Teknik Industri. 50-58. 
International Journal of Computer and Information System (IJCIS)

Peer Reviewed - International Journal

Vol : Vol. 02, Issue 03, Agustus 2021

e-ISSN : 2745-9659

https://ijcis.net/index.php/ijcis/index

[9.] Nastiti, Heni. 2013. Analisis Pengendalian Kualitas Produk Dengan Metode Statistical Quality Control. Jurnal Manajemen. 414-423.

[10.] Nasution, M. N. 2005. Manajemen Mutu Terpadu. Bogor : Ghalia Indonesia.

[11.] Norawati, Suarti dan Zulher.2019. Analisis Pengendalian Mutu Produk Roti Manis dengan Metode Statistical Process Control (SPC) pada Kampar Bakery Bangkinang.Jurnal Ekonomi.103-110.

[12.] Prawirosentono, Suyadi. 2007. Filosofi Baru Tentang Manajemen Mutu Terpadu Abad 21 "Kiat Membangun Bisnis Kompetitif”. Jakarta:Bumi Aksara.

[13.] Suhartini, Nanih. 2020. Penerapan Metode Statistical Process Control (SPC) dalam Mengidentifikasi Faktor Penyebab Utama Kecacatan pada Proces Produk ABC. Jurnal Ilmiah Teknologi dan Rekayasa.10-23.

[14.] Tannady, Henndy.2015. Pengendalian Kualitas. Graha Ilmu. Jakarta Utara.

[15.] Muqorobin, M., Kusrini, K., Rokhmah, S., \& Muslihah, I. (2020). Estimation System For Late Payment Of School Tuition Fees. International Journal of Computer and Information System (IJCIS), 1(1), 1-6.

[16.] Muryani, A. S., \& Muqorobin, M. (2020). Decision Support System Using Cloud-Based Moka Pos Application To Easy In Input In Orange Carwash Blulukan Flash NO. 110 Colomadu. International Journal of Computer and Information System (IJCIS), 1(3), 66-69. 